\title{
Primary Neural Leprosy mimicking rheumatological disorders
}

Denata Carolina Schlögel de Freitas ${ }^{1}$ (iD) Carlos Augusto Zanardini Pereira ${ }^{1}$

(iD) Nadia Tannous Muri ${ }^{1}$

Valéria Aparecida Zanela Franzon ${ }^{1}$ (D) Carlos Alberto Camorim Fatuch ${ }^{1}$

\section{SUMMARY}

Leprosy is a chronic infectious disease caused by Mycobacterium leprae, which affects mainly the skin and peripherical nerves. Brasil has not yet achieved its goal of elimination of the number of cases of this disease, ranking second in terms of absolute numbers worldwide, with India occupying the first position. Primary Neural Leprosy is considered to be a challenge in diagnosis, since it affects the peripherical nerve system with the absence of skin lesions, thus mimicking rheumatological disorders, like in the case presented. A male, 31, with no previous comorbidities, five years ago, started feeling severe pain in the left ankle as well as morning hand pain and stiffness. After many years of being submitted to intense rheumatological disease investigation, they all proved to be negative. Upon physical examination, the patient presented no skin lesions, symmetric polyarthritis in metacarpophalangeal joints and thickness of the left sural nerve. Lab exams showed no alterations and bacilloscopy was negative. Ultrasonography was used to investigate the thickness of the left sural nerve. Biopsy showed a minimal amount of perineural lymphocytes and positive AFB testing. Based on the electroneuromyography, the conclusion was multiple mononeuropathy, and multibacillary polychemotherapy was started. Leprosy remains a public health problem in Brasil. Due to the high prevalence of the disease, our medical colleagues must be alert and trained to recognize this clinical presentation of leprosy. Correct referral to Reference Centers accelerates research, contributing to an accurate diagnosis, classification, and treatment, thus preventing irreversible sequelae with severe functional disability.

KEYWORDS: Leprosy. Mycobacterium leprae. Mononeuropathies. Arthritis.

\section{INTRODUCTION}

Leprosy is an infectious disease, caused by Mycobacterium leprae or Hansen bacillus, that affects the skin and/or peripheral nerves ${ }^{1-3}$.

It is a chronic disease and presents periods of exacerbation, which we called leprosy reactions ${ }^{1}$. Its clinical presentation depends on the immune response of the host ${ }^{1-4}$. The elimination of the bacilli occurs through the upper airways, and the bacillary patient is the main source of transmission ${ }^{2,4-6}$.
Brasil has not yet reached the goal of eliminating the disease, and occupies the second position in the worldwide rank, behind only of India ${ }^{2,4-6}$. The disease continues to be a public health problem, since, when left untreated and not diagnosed early, it may lead to irreversible sequelae with significant functional damage ${ }^{1,2,4-6}$.

Primary neural leprosy (PNL) is considered a challenging diagnosis because it affects the periph-

DATE OF SUBMISSION: 15-Jan-2019

DATE OF ACCEPTANCE: 10-Feb-2019

CORRESPONDING AUTHOR: Renata Carolina Schlögel de Freitas

Rua Suécia 588 Tarumã, Curitiba - PR, Brasil, CEP 82800-060

Tel: (41) 3267-7548 / (41) 98439-9696

E-mail: re_csf@yahoo.com.br 
eral nervous system without the presence of skin lesions, thus often mimicking rheumatological diseases, such as in the case described below ${ }^{1,3,5}$.

\section{CASE REPORT}

A male, 31 years old, born and resident in Contenda/PR, truck driver, without previous comorbidities. Approximately five years ago, he began feeling a strong burning pain on the left ankle, associated with pain and morning stiffness on the hands. Forwarded to a rheumatology service, he began treatment with hydroxychloroquine and methotrexate, without improvement. For years, an extensive investigation for rheumatic diseases was conducted but proved negative. Upon physical examination, the patient appeared to be in good general condition, without skin lesions, symmetric polyarthritis in the metacarpophalangeal joints and thickening of the left sural nerve. Laboratory exams showed no changes and bacilloscopy was negative. During an ultrasound, we observed the thickening of the left sural nerve with a hypoechoic and heterogeneous aspect, measuring $2.9 \mathrm{~mm}$ of transverse diameter and $0.10 \mathrm{~cm}^{2}$ of sectional area (Figure 1). A biopsy of the sural nerve showed a minimal amount of lymphocytes, and the AFB reading was positive. In electromyography, we found the sensory nerve action potentials (SNAP) of the sural nerve were abolished. The PANS of the right superficial fibular nerve had slightly reduced amplitudes. The compound muscle action potentials (CMAP) of the posterior tibial nerves had a mild reduction of amplitudes, bilaterally, and signs of proximal temporal dispersion. In this way, the conclusion was of multiple mononeuropathies. So multibacillary polychemotherapy was started.

\section{DISCUSSION}

Primary neural leprosy is characterized by peripheral nerve involvement in the absence of skin lesions and with a negative bacilloscopy ${ }^{1,3,5,7}$.

The patient may present symptoms such as intense burning pain, paresthesia, thermal and painful anesthesia, hypohidrosis, motor losses, the involvement of soft parts, arthritis in small and large joints, thickening of the nerves, and pain upon palpation ${ }^{1,4,5,8}$.

The symptoms may be the first manifestation of the disease or can be triggered by leprosy reactions ${ }^{4.9}$.

FIGURE 1. ULTRASOUND IMAGE SHOWING THICKENING OF THE LEFT SURAL NERVE WITH HYPOECHOIC AND HETEROGENEOUS ASPECT. THE TIP OF THE WHITE ARROW INDICATES THE TRANSVERSE DIAMETER THAT CORRESPONDS TO 2.9 MM. THE GRAY ARROW INDICATES THE SECTIONAL AREA OF $0.10 \mathrm{CM}^{2}$.

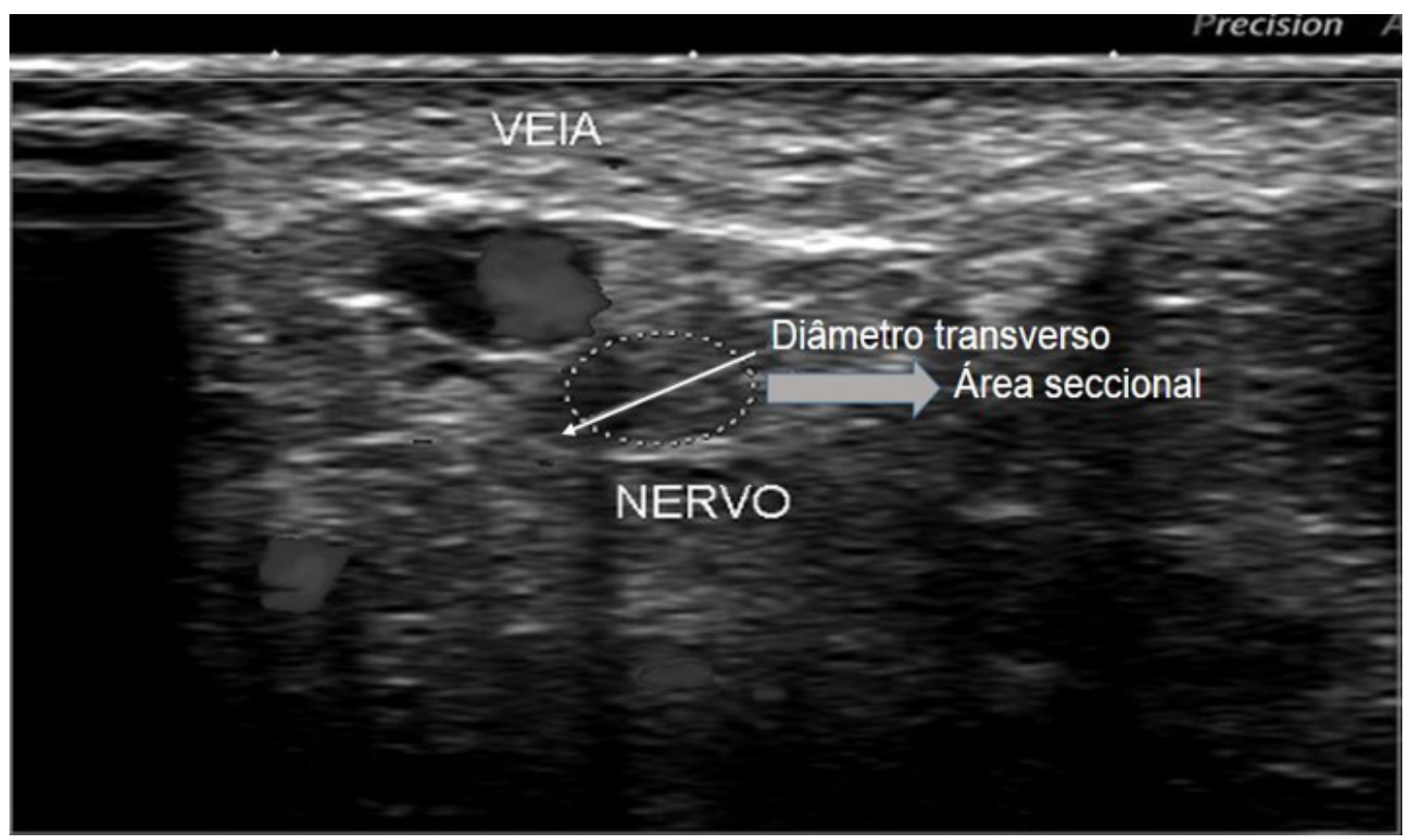


Among differential diagnoses, we can mention rheumatoid arthritis, spondyloarthropathies, collagenosis, vasculitis, diabetes, hypothyroidism, tumors, Aids, syphilis, traumatic causes, among others ${ }^{2,4,7,9,10}$.

When there is clinical suspicion of primary neural leprosy, a nerve biopsy, in particular of a sensory nerve, can be performed to confirm the diagnosis ${ }^{6.7}$. In such cases, the sural nerve is the first choice ${ }^{7}$.

Although the nerve biopsy has greater sensitivity, a skin biopsy can be performed in areas with hypoesthesia or in the area of the path of the affected nerve ${ }^{5,7,10}$. Histopathological findings often present nonspecific alterations; however, this does not exclude the diagnosis of leprosy ${ }^{5.6}$.

Ultrasound can be used as a complementary diagnostic method or for patient follow-up. The examination shows the morphology of the nerve and may evidence signs of active inflammation in the periph-

FIGURES 2 AND 3. ELECTROMYOGRAPHY TRACING SHOWING THE ABOLISHED SENSORY NERVE ACTION POTENTIALS OF THE LEFT SURAL NERVE.
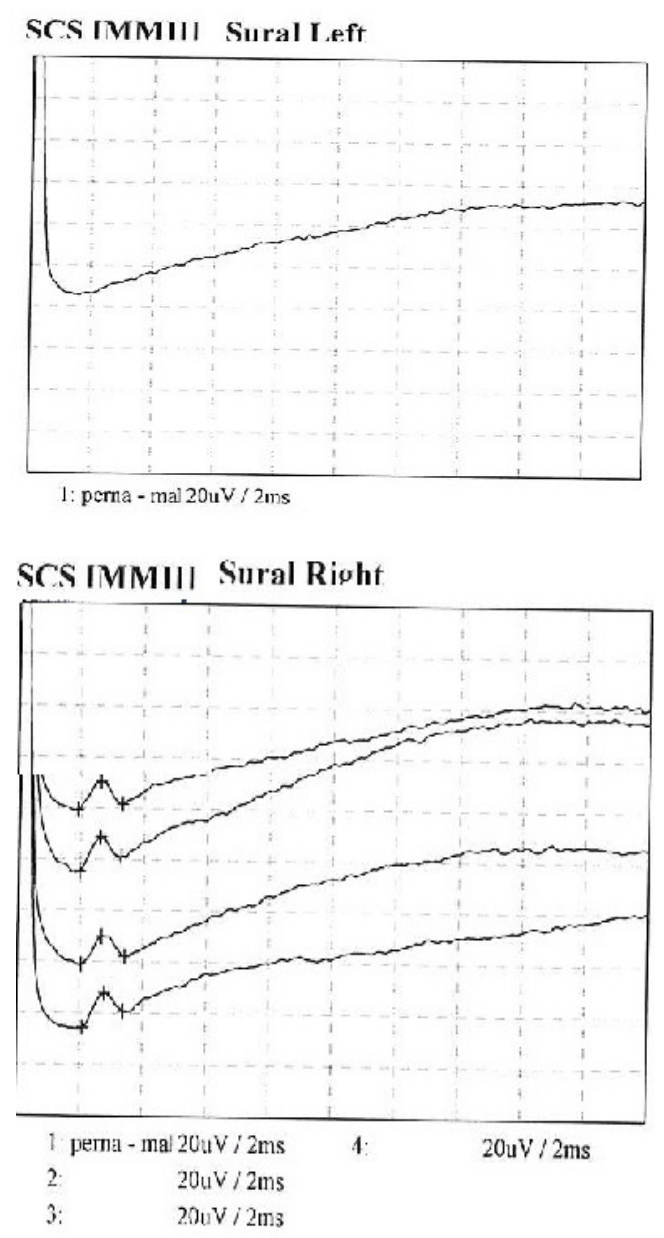

eral nerves through echotexture, thickening, and vascularization ${ }^{5}$.

Electroneuromyography (EMNG) provides information that allows us to characterize the location and distribution of the neural injury ${ }^{7.8}$. EMNG can assist in the choice of the nerve that will be biopsied at the time of diagnosis or used in the monitoring of the patients ${ }^{1,6-8}$.

The leprous neuropathy is mixed and affects autonomic, sensory, and motor nerves ${ }^{1,3,5}$. In leprosy, the most common type of neural involvement is the multiple mononeuropathy, that is, the involvement of more than one nervous trunk asymmetricaly ${ }^{5,7,10}$.

The treatment with polychemotherapy should be started according to the classification as paucibacillary (involvement of only one nerve) or multibacillary (when there is more than one nerve affected) 3,7,10. $^{3}$.

In primary neural leprosy, skin involvement is not identified initially, but some patients develop skin lesions after the diagnosis is defined. During the treatment, the patient has a clinical follow-up and thorough dermatological examination in search of discrete skin lesions not previously displayed ${ }^{7}$. Thus, some initial diagnoses of primary neural leprosy can be reclassified as other forms of leprosy? ${ }^{7}$.

\section{CONCLUSION}

Primary neural leprosy is considered a challenging diagnosis. The long incubation period, insidious symptoms, and absence of skin lesions can delay the diagnosis, increasing the potential for the development of neurological sequelae.

Faced with a scenario of arthritis without a definite diagnosis and associated with paresthesia and/ or neural thickening, the hypothesis of primary neural leprosy should be considered.

It is important to stress that the absence of skin lesions and negative bacilloscopy in skin serosity do not rule out the possibility of multibacillary leprosy.

Leprosy remains a public health problem in Brasil. Due to the high prevalence of the disease, it is necessary that our medical colleagues are alert and trained to recognize the clinical presentation of leprosy. The correct referral to reference centers accelerates the investigation, contributing to early diagnosis, classification, and correct treatment, thus preventing irreversible sequelae that cause severe functional disability. 


\section{RESUMO}

A hanseníase é uma doença infectocontagiosa causada pelo Mycobacterium leprae e acomete a pele elou nervos periféricos. O Brasil ainda não atingiu a meta de eliminação da doença, estando em segundo lugar no ranking mundial, perdendo somente para a Índia. A hanseníase neural primária é considerada um desafio diagnóstico, pois acomete o sistema nervoso periférico sem a presença de lesões cutâneas, podendo mimetizar doenças reumatológicas, como no caso descrito a seguir. Masculino, 31 anos, sem comorbidades prévias. Há cinco anos iniciou com dor forte em tornozelo esquerdo, associado à dor e rigidez matinal em mãos. Durante anos realizou investigação extensa para doenças reumatológicas, que se mostrou negativa. Ao exame físico, paciente sem lesões dermatológicas, poliartrite simétrica em articulações metacarpofalangeanas e espessamento do nervo sural esquerdo. Exames laboratoriais sem alterações e baciloscopia negativa. Ao ultrassom, espessamento do nervo sural esquerdo. Biópsia do nervo sural com mínima quantidade de linfócitos perineural e pesquisa de BAAR positivo. Na eletroneuromiografia, a conclusão foi de mononeuropatia múltipla, iniciando, então, poliquimioterapia multibacilar. A hanseníase continua sendo um problema de saúde pública no Brasil. Devido à elevada prevalência da doença, é necessário que nossos colegas médicos estejam alertas e capacitados para o reconhecimento desta forma clínica da hanseníase. O encaminhamento correto para centros de referência acelera a investigação, contribuindo para um diagnóstico precoce, classificação e tratamento corretos, prevenindo sequelas irreversíveis com grave incapacidade funcional.

PALAVRAS-CHAVE: Hanseníase. Mycobacterium leprae. Mononeuropatias. Artrite.

\section{REFERENCES}

1. Nascimento OJ. Leprosy neuropathy: clinical presentations. Arq Neurop $1(9-B): 661-6$

2. Lastória JC, Abreu MA. Leprosy: review of the epidemiological, clinical, and etiopathogenic aspects - part 1. An Bras Dermatol. 2014;89(2):205-18.

3. Santos DFD, Mendonça MR, Antunes DE, Sabino EFP, Pereira RC, Goulart LR, et al. Revisiting primary neural leprosy: clinical, serological, molecular, and neurophysiological aspects. PLoS Negl Trop Dis. 2017;11(11):e0006086.

4. Fernandes TRMO, Korinfskin JP, Espíndola MMM, Corrêa LMO. Artrite como diagnóstico de hanseníase: relato de caso e revisão da literatura. An Bras Dermatol. 2014;89(2):328-30.

5. Tomaselli P. Hanseníase forma neural pura: aspectos clínicos e eletroneuromiográficos dos pacientes avaliados no serviço de doenças neuromusculares do HCRP da USP no período de março de 2001 a março de 2013 [Dissertação de mestrado]. Ribeirão Preto: Faculdade de Medicina, Universidade de São Paulo; 2014. 97p.
6. Castro FRS. Alterações neurológicas na forma neural pura da hanseníase: aplicação do grau de incapacidade física e da classificação internacional de funcionalidade, incapacidade e saúde [Dissertação de mestrado]. Rio de Janeiro: Instituto Oswaldo Cruz, Pós-graduação em Medicina Tropical; 2012. 103p.

7. Garbino JA, Jardim MR, Marques Jr W, Antunes SL, Soares CT, Heise CO, et al. Hanseníase neural primária. Projeto Diretrizes. São Paulo: Associação Médica Brasileira, Conselho Federal de Medicina; 2011.

8. Garbino JA. O paciente com suspeita de hanseníase primariamente neural. Hansen Int. 2007;32(2):203-6.

9. Prasad S, Misra R, Aggarwal A, Lawrence A, Haroon N, Wakhlu A, et al. Leprosy revealed in a rheumatology clinic: a case series. Int J Rheum Dis. 2013;16(2):129-33.

10. Garbino |A, Marques |r W, Barreto |A, Heise CO, Rodrigues MM|, Antunes $\mathrm{SL}$, et al. Primary neural leprosy: systematic review. Arq Neuropsiquiatr. 2013;71(6):397-404. 